\title{
Antibacterial constituents of the leaves of Dacryodes edulis
}

\author{
Kola K. Ajibesin ${ }^{1 *}$, Etienne E. Essien ${ }^{2}$ and Saburi A. Adesanya ${ }^{3}$ \\ ${ }^{1}$ Department of Pharmacognosy and Herbal Medicine, Niger Delta University, Wilberforce Island, Bayelsa State, Nigeria. \\ ${ }^{2}$ Department of Pharmaceutical and Medicinal Chemistry, University of Uyo, Uyo, Nigeria. \\ ${ }^{3}$ Department of Pharmacognosy, Obafemi Awolowo University, Ile-Ife, Nigeria.
}

Accepted 5 October, 2011

\begin{abstract}
Dacryodes edulis is a dioecious, small to medium-sized tree, reaching 20 to $25 \mathrm{~m}$ high. Different parts of the plant are used to treat many diseases including skin infections, digestive tract disorder and dysentery. The leaves were macerated in $50 \%$ ethanol and the liquid extract concentrated to dryness. The dry extract was evaluated for antibacterial activity by using agar diffusion method. The extract was partitioned between water, ethyl acetate and butanol successively and further subjected to antibacterial testing. The most active fraction, ethyl acetate fraction, was purified through various chromatographic methods to obtain pure compounds identified by spectroscopic methods as ethylgallate and quercitrin. These compounds gave good antibacterial effects, while the minimum inhibitory concentrations of the fractions and the pure compounds ranged between 12.5 and $250 \mu \mathrm{g} / \mathrm{ml}$. These phenolic compounds are reported for the first time in this plant.
\end{abstract}

Key word: Dacryodes edulis, antibacterial activity, ethylgallate, quercitrin.

\section{INTRODUCTION}

Dacryodes edulis is a dioecious, small to medium-sized tree reaching 20 to $25 \mathrm{~m}$ high, and it is low branching (Hutchinson and Dalziel, 1958). The decoction of the leaves of the plant is employed in traditional medicine in the treatment of certain disorders of the digestive tract, toothache and earache. The leaf and stem or stem bark are used to cure dysentery and anaemia (Ayuk et al., 1999). The root bark is used for leprosy in Congo Brazaville (Bouquet, 1969), while resin from the bark heals scars and other skin problems in Nigeria (Ekong and Okogun, 1969; Burkill, 1985). In Nigeria, the stem and root are also used as chewing sticks for oral hygiene, while the leaves are employed to cure skin diseases, such as rashes, scabies, ringworm and wound (Igoli et al., 2005; Ajibesin et al., 2008). The fruit and seed of the plant are rich in oil which contains lipid and fatty acid reported to exhibit considerable nutritional value (Obasi and Okoli, 1993; Kinkela et al., 2006). Different parts of the plant, such as the leaf, stem, root and fruit have been

${ }^{*}$ Corresponding author. E-mail: kay_ajib@yahoo.com. Tel: +2348038937431 . reported to produce essential oil of the monoterpene, sesquiterpene, diterpene and triterpene types (Ekong and Okogun, 1969; Jirovetz et al., 2003; Onocha et al., 1999). Antibacterial effect of the essential oil has been reported (Obame et al., 2008), but no report on the organic extract of the plant and its chemical constituents is available.

Thus, applying activity guided purification, this study aimed at validating the antibacterial effect of the plant and identifying the chemical constituents responsible for such effect.

\section{MATERIALS AND METHODS}

The nuclear magnetic resonance (NMR) spectra were recorded on a Brucker DR-500 MHz $\left({ }^{1} \mathrm{H} 1\right)$ and $25 \mathrm{MHz}\left({ }^{1} \mathrm{H} /{ }^{13} \mathrm{C}\right.$ HETCOR), in $\mathrm{CD}_{3} \mathrm{OD}$ using tetramethylsilane (TMS) as internal standard. Mass spectroscopy was determined using Electro spray ionization (ESI) Full MS and Finnigan LCQ Deca-MS, Agilent series 1100-LC. UV spectroscopy was determined by Dionex, UVD 340 S Dionex. Melting points were determined on a Kofler hot-stage microscope (uncorrected). Thin layer chromatography (TLC) was carried out on silica gel $60 \mathrm{~F}_{254}$ (Merck). Solvent systems, such as $\mathrm{EtOAc}-\mathrm{CH}_{3} \mathrm{OH}$; 8:2 (A), $\mathrm{CH}_{2} \mathrm{Cl}_{2}-\mathrm{MeOH}$; 9:1 (B), EtOAc-n- $\mathrm{C}_{6} \mathrm{H}_{14} ; 4: 1$ (C), $\mathrm{CH}_{2} \mathrm{Cl}_{2}-$ $\mathrm{MeOH} ; 7: 3$ (D) and $\mathrm{CH}_{2} \mathrm{Cl}_{2}-\mathrm{MeOH}-\mathrm{H}_{2} \mathrm{O}$; (7:3:1) were used. UV light ( $\lambda$ max 254 and $366 \mathrm{~nm}$ ), $\mathrm{FeCl}_{3}$ spray, vanillin/ $\mathrm{H}_{2} \mathrm{SO}_{4}$ and conc. 
$\mathrm{H}_{2} \mathrm{SO}_{4}$ sprays followed by activating at $100^{\circ} \mathrm{C}$ for $5 \mathrm{~min}$, were used for detection of spots.

\section{Plant}

The leaves $(6 \mathrm{~kg})$ of $D$. edulis were collected in June, 2005, at Ikot Ekpene in Akwa lbom State, Nigeria. The plant was identified and authenticated by Dr. U. Essiett of the Department of Botany, University of Uyo, Uyo, Nigeria. Voucher specimen (KKA 21) was deposited in the Department of Pharmacognosy and Natural Medicine herbarium, Faculty of Pharmacy, University of Uyo, Uyo, Nigeria.

\section{Extraction of the plant}

The dried leaf powder $(4 \mathrm{~kg})$ of $D$. edulis was extracted by maceration using $50 \% \mathrm{EtOH}(10 \mathrm{~L})$. It was filtered and the marc was re-extracted with the fresh solvent mixture for $12 \mathrm{~h}(\mathrm{x} 2)$ and filtered. The filtrates were pooled together and concentrated to dryness in vacuo at $40^{\circ} \mathrm{C}$ to yield dry ethanol extract $(80 \mathrm{~g})$.

The dry ethanol extract $(60 \mathrm{~g})$ was dissolved in water and successively shaken with EtOAc $(6 \times 300 \mathrm{ml})$ and $\mathrm{BuOH}(6 \times 300$ $\mathrm{ml}$ ) to afford ethyl acetate (18 g), butanol (20 g) and aqueous fractions $(20 \mathrm{~g})$, respectively.

\section{Antibacterial test}

The bacteria used in this study were Bacillus cereus (NCIB 6349), Staphylococcus aureus (NCIB 8588), Pseudomonas aeruginosa (NCIB 950) and Escherichia coli (NCIB 86). All the organisms were obtained from the Department of Microbiology, Obafemi Awolowo University, Ile-Ife, Nigeria. They were maintained on blood agar slants at $4^{\circ} \mathrm{C}$ prior to use.

The extract and the fractions were reconstituted in $\mathrm{MeOH}-\mathrm{H}_{2} \mathrm{O}$ $(1: 1)$ to obtain a stock solution of $20 \mathrm{mg} / \mathrm{ml} .50 \mu \mathrm{l}$ of this solution was introduced into each of the equidistant wells $(8 \mathrm{~mm})$ bored on the agar plate surface previously inoculated with each of the test organisms. A control well containing Gentamicin $(5 \mu \mathrm{g} / \mathrm{ml})$ was placed in each of the plates seeded with bacteria. The Petri plates were then incubated at $37^{\circ} \mathrm{C}$ for $24 \mathrm{~h}$ (Alade and Irobi, 1993; Igbinosa et al., 2009). Antibacterial activity was expressed as average diameter of the zones of inhibition calculated as a difference in diameter of the observed zones and those of the wells.

\section{Activity-guided fractionation of $D$. edulis}

The antibacterial principles were partitioned mostly into ethyl acetate fraction followed by butanol and aqueous fractions, respectively, and these were subjected to further fractionation using different chromatographic techniques.

\section{Minimum inhibitory concentration (MIC)}

The MIC was determined by incorporating various amounts (250 to $6.25 \mu \mathrm{g} / \mathrm{ml}$ ) of the solution of the extracts and fractions into sets of test tubes containing the culture media. $50 \mu \mathrm{l}$ of the standard test bacterial broth cultures were added into each of the test tubes. The set of tubes containing a mixture of bacteria and the sample (extracts and fractions) were incubated at $37^{\circ} \mathrm{C}$ for $24 \mathrm{~h}$ (Cos et al., 2006).

A positive control tube containing only the growth medium of each of the organisms was also set up. The MIC was regarded as The lowest concentration of the extract or fraction that did not permit any visible growth when compared with that of the control tubes.

\section{Isolation and characterization}

The EtOAc, butanol and aqueous fractions of the plant species were subjected to TLC analysis, using solvent systems $A, B, C$ and $E$, respectively and visualized under the UV light $(\lambda 254 \mathrm{~nm})$ before using $100 \% \mathrm{H}_{2} \mathrm{SO}_{4}$ and $\mathrm{FeCl}_{3}$ solution as detecting spray reagents. The most active EtOAc fraction $(18 \mathrm{~g})$ showed phenolic components and was chromatographed on silica (Merck, 0.040 to $0.063 \mathrm{~mm}$ particle size) by accelerated gradient chromatography (AGC) column and eluted with $\mathrm{C}_{6} \mathrm{H}_{14}$ containing increasing amount of EtOAc followed by increasing amount of $\mathrm{CH}_{3} \mathrm{OH}(9: 1,9: 1)$. Six fractions coded $A, B, C, D, E$ and $F$ were obtained, two (A and $C)$ of which showed significant antibacterial effects. The more active $(A)$ of the two fractions was further fractionated on silica by repeated AGC, using $\mathrm{C}_{6} \mathrm{H}_{14}$ in gradient with $\mathrm{CH}_{2} \mathrm{Cl}_{2}$ and $\mathrm{CH}_{3} \mathrm{OH}$ (9.5:5, 9.5:5; $5: 5,9.8: 0.2)$ to yield $1(55 \mathrm{mg})$. The less active fraction was purified by vacuum liquid chromatography (VLC) using $\mathrm{CH}_{2} \mathrm{Cl}_{2}$ in gradient with $\mathrm{CH}_{3} \mathrm{OH}$ and $\mathrm{H}_{2} \mathrm{O}$ (7:2:1), AGC (silica) and on Sephadex LH 20, eluted isocratically with $\mathrm{EtOH}$. Final purification was carried out on silica by preparative thin layer chromatography (prep. TLC), using $\mathrm{CH}_{2} \mathrm{Cl}_{2}-\mathrm{CH}_{3} \mathrm{OH}(4: 1)$ as mobile phase to yield $2(10 \mathrm{mg})$. The two compounds were also subjected to antibacterial test.

Ethylgallate 1: Silky, fluffy, white crystals, mp 160 to $162^{\circ} \mathrm{C}$ $(\mathrm{MeOH}),{ }^{1} \mathrm{HNMR}\left(\mathrm{CD}_{3} \mathrm{OD}\right): \delta 1.33\left(3 \mathrm{H}, \mathrm{t}, \mathrm{O}-\mathrm{CH}_{2}-\mathrm{CH}_{3}\right), 4.28(2 \mathrm{H}, \mathrm{q}$, $\left.\mathrm{O}-\mathrm{CH}_{2}-\mathrm{CH}_{3}\right)$ and $7.08(2 \mathrm{H}, \mathrm{s}, \mathrm{Ar} . \mathrm{H})$.

Quercitrin 2: yellow powder, mp $210^{\circ} \mathrm{C}(\mathrm{MeOH}), \mathrm{UV} \mathrm{CH}_{3} \mathrm{OH} \lambda$ max nm: 256, 350. ESI Full MS - m/z (rel. int.): $447[\mathrm{M}+\mathrm{H}]^{+}(100)$ and $301[\mathrm{M}+\mathrm{H}-\mathrm{Rham} .]^{+}(60)$. ${ }^{1} \mathrm{HNMR}\left(\mathrm{CD}_{3} \mathrm{OD}\right): \delta 6.20(1 \mathrm{H}, \mathrm{d}, \mathrm{J}=$ $2.5 \mathrm{~Hz}, \mathrm{H}-6), 6.40(1 \mathrm{H}, \mathrm{d}, \mathrm{J}=2.5 \mathrm{~Hz}, \mathrm{H}-8), 6.90(1 \mathrm{H}, \mathrm{d}, \mathrm{J}=8.0 \mathrm{~Hz}$, $\left.\mathrm{H}^{-5}\right), 7.30\left(1 \mathrm{H}, \mathrm{dd}, \mathrm{J}=8.0 \mathrm{~Hz}, \mathrm{H}-6^{\prime}\right), 7.35\left(1 \mathrm{H}, \mathrm{d}, \mathrm{J}=1.6 \mathrm{~Hz}, \mathrm{H}-2^{\prime}\right)$, $5.35\left(1 \mathrm{H}, \mathrm{s}, \mathrm{H}-1^{\prime \prime}\right), 4.20\left(1 \mathrm{H}, \mathrm{d}, \mathrm{H}-2\right.$ "), $3.75\left(1 \mathrm{H}, \mathrm{dd}, \mathrm{H}-3^{\prime \prime}\right), 3.30(1 \mathrm{H}$, d, $\mathrm{H}-4 "), 3.40(1 \mathrm{H}, \mathrm{m}, \mathrm{H}-5)$ and $0.94(3 \mathrm{H}, \mathrm{d}, \mathrm{H}-6 ")$.

${ }^{1} \mathrm{H} /{ }^{13} \mathrm{C}\left(\mathrm{CD}_{3} \mathrm{OD}\right): \delta 99.3(\mathrm{C}-6), 94.2(\mathrm{C}-8), 116.0\left(\mathrm{C}-5^{\prime}\right), 122.4\left(\mathrm{C}-6^{\prime}\right)$, 116.5 (C-2'), 103.4 (C-1"), 71.5 (C-2"), 71.5 (C-2"), 71.8 (C-3"), 72.7 (C-4"), 72.5 (C-5") and 17.2 (C-6").

\section{RESULTS AND DISCUSSION}

Two phenolic compounds were isolated from the leaves of $D$. edulis. Ethylgallate 1, a silky, fluffy, white crystal was isolated with the aid of accelerated gradient chromatography (AGC), while quercitrin 2 was separated with vacuum liquid chromatography (VLC), accelerated gradient chromatography (AGC), size exclusion chromatography (Sephadex LH-20) and preparative thin layer chromatography (prep. TLC).

The ${ }^{1} \mathrm{HNMR}$ spectrum of compound 1 gave a triplet at $\delta$ 1.33 representing three methyl protons, and a quartet at $\delta 4.28$ indicating two methylene protons of $\mathrm{O}-\mathrm{CH}_{2}-\mathrm{CH}_{3}$ group. Presence of a sharp singlet at $\delta 7.08$ corresponds to two aromatic protons, indicating the symmetrical nature of the molecule. It also suggests the attachment of hydroxyl group at 3-, 4- and 5- positions. These data agree with the literature values (Metha and Sharma, 1988; Adesina et al., 2000). On this basis, compound 1 was characterized as ethylgallate (Ethyl 3, 4, 5trihydroxybenzoate).

Quercitrin 2 exhibited band I and band II with the UV 
Table 1. Antibacterial activity of the extracts of $D$. edulis leaf

\begin{tabular}{|c|c|c|c|c|c|c|}
\hline \multirow{2}{*}{ Microorganism } & \multicolumn{6}{|c|}{ Zone of inhibition of organisms $(\mathrm{mm})^{a}$} \\
\hline & $\mathbf{L}$ & $\mathbf{E}$ & B & $\mathrm{Aq}$ & Gen & $\mathrm{MeOH}: \mathrm{H}_{2} \mathrm{O}$ \\
\hline E. coli NCIB 86 & $8 \pm 1.00^{*}$ & $8 \pm 1.41^{*}$ & $3 \pm 1.00$ & $4 \pm 1.41$ & $12 \pm 1.58^{*}$ & 0 \\
\hline B. cereus NCIB 6349 & $13 \pm 1.00$ * & $12 \pm 1.73^{*}$ & $5 \pm 2.12$ & $5 \pm 2.20$ & $13 \pm 1.41^{*}$ & 0 \\
\hline S. aureus NCIB 8588 & $10 \pm 1.41^{*}$ & $11 \pm 1.58^{*}$ & $6 \pm 1.00^{*}$ & $4 \pm 0.00$ & $13 \pm 1.00^{*}$ & 0 \\
\hline P. aeruginosa NCIB 950 & $9 \pm 1.00^{*}$ & $8 \pm 0.00^{*}$ & $4 \pm 1.00$ & $3 \pm 1.00$ & $15 \pm 2.12^{*}$ & 0 \\
\hline
\end{tabular}

L, Leaf ethanol extract; $E$, ethyl acetate extract; B, butanol extract; Aq, aqueous extract, Gen, gentamicin. Values are mean \pm SD $(n=4)$, ${ }^{*} P<$ 0.01 with respect to control.

Table 2. Antimicrobial activity of the fractions of $D$. edulis leaf.

\begin{tabular}{|c|c|c|c|c|c|c|c|c|c|c|}
\hline Microorganism & $\mathbf{A}$ & B & C & D & $\mathbf{E}$ & $\mathbf{F}$ & 1 & 2 & Gen & $\mathrm{MeOH}: \mathrm{H}_{2} \mathrm{O}$ \\
\hline E. coli NCIB 86 & $12 \pm 1.00^{*}$ & $5 \pm 0.00$ & $8 \pm 1.00^{*}$ & $3 \pm 1.00$ & $3 \pm 2.00$ & $2 \pm 0.00$ & $17 \pm 1.00^{*}$ & $14 \pm 2.12^{*}$ & $15 \pm 1.58^{*}$ & 0 \\
\hline B. cereus NCIB 6349 & $16 \pm 1.00^{*}$ & $5 \pm 2.12$ & $10 \pm 1.00^{*}$ & $3 \pm 0.00$ & $1 \pm 0.00$ & $2 \pm 0.00$ & $26 \pm 2.00^{*}$ & $15 \pm 2.35^{*}$ & $19 \pm 1.41^{*}$ & 0 \\
\hline S. aureus NCIB 8588 & $14 \pm 1.00^{*}$ & $3 \pm 1.73$ & $8 \pm 1.00^{*}$ & 0 & 0 & 0 & $21 \pm 1.73^{*}$ & $15 \pm 1.00^{*}$ & $20 \pm 1.00^{*}$ & 0 \\
\hline P. aeruginosa NCIB 950 & $9 \pm 1.73^{*}$ & $3 \pm 2.00$ & $6 \pm 1.73$ & 0 & 0 & 0 & $15 \pm 1.00^{*}$ & $10 \pm 1.00$ & $15 \pm 2.12^{*}$ & 0 \\
\hline
\end{tabular}

Gen, gentamicin, values are mean $\pm S D(n=4) ;{ }^{*} P<0.01$ with respect to control.

spectrum at $\lambda \max \mathrm{nm}: 350.0,256.0 \mathrm{~nm}$, respectively, indicating it to be $3-0$ - substituted flavonol (Bilia et al., 1993; Ibewuike, 1997). The ESI full mass spectrum showed a $[\mathrm{M}+\mathrm{H}]^{+}$peak at $\mathrm{m} / \mathrm{z} 447\left(\mathrm{C}_{21} \mathrm{H}_{20} \mathrm{O}_{11}\right)$ as the base peak. Retro Diels Alder (RDA) fragment at $\mathrm{m} / \mathrm{z} 301.2$ showed the loss of rhamnose.

In the ${ }^{1} \mathrm{HNMR}$ spectrum, the glycosidic nature of the compound was shown by the presence of a sugar moiety at $\delta 3.3$ to 4.3 . In the sugar portion, a doublet at $\delta 3.75(\mathrm{H}-3$ ") coupled with a doublet each at $\delta 3.3(\mathrm{H}-4 ")$ and $\delta 3.75(\mathrm{H}-2 ")$. The sugar moiety was inferred to be rhamnose from the methyl proton signal at $\delta 0.94(3 \mathrm{H}, \mathrm{d}, \mathrm{H}-6 ")$, which was splited into a doublet by a proton at $\delta 3.4(1 \mathrm{H}$, $\mathrm{m}, \mathrm{H}-5 ")$. The aromatic doublets at $\delta 6.20$ and $6.40(\mathrm{~J}=2.5 \mathrm{~Hz}, \mathrm{H}-6, \mathrm{H}-8)$ were caused by $\mathrm{m}$ - coupled protons of an $A B$ system characteristic of a 5,7 -substituted ring $A$. The signals at $\delta 6.90$ $\left(1 \mathrm{H}, \mathrm{d}, \mathrm{J}=8.0 \mathrm{~Hz}, \mathrm{H}-5^{\prime}\right)$ and $\delta 7.30(1 \mathrm{H}, \mathrm{dd}, \mathrm{J}=$ $1.6 \mathrm{~Hz}, \mathrm{H}-6^{\prime}$ ) showed o-coupled protons on ring $\mathrm{B}$, while the signal at $\delta 7.35\left(1 \mathrm{H}, \mathrm{d}, \mathrm{J}=1.6 \mathrm{~Hz}, \mathrm{H}-2^{\prime}\right)$ exhibited m-coupled, all of an $A B C$ system, characteristic of 3', 4'-substituted ring B.

The ${ }^{1} \mathrm{H} /{ }^{13} \mathrm{C}$ COSY (HECTOR) spectrum showed the characteristic rhamnose methyl signal at $\delta$ 17.2. It also indicated the other sugar carbon signals at $\delta 71.5$ to 72.7 , with the anomeric carbon evident at $\delta$ 103.4. Thus, compound 2 was identified as quercitrin (quercitrin -3-Orhamnoside). This was confirmed by HPLC-UV (Chromeleon Dionex) of the authentic sample as well as by comparison with literature values (Bombardelli et al., 1973; Lin et al., 2002).
The extract, fractions and the pure compounds isolated showed varying degrees of antibacterial activities against all the tested microorganisms (Tables 1 and 2). These test bacteria have been implicated in the pathogenesis of human infections (Duguid et al., 1978). The ethanol extract gave the highest activity against $B$. cereus with inhibition zone of $13 \mathrm{~mm}$, followed by $S$. aureus with the inhibition zone of $10 \mathrm{~mm}$. The good activity elicited by ethanol extract was partitioned into ethyl acetate fraction, which also showed significant activity against $B$. cereus with zone of inhibition of $12 \mathrm{~mm}$ and $S$. aureus with zone of inhibition of $11 \mathrm{~mm}$. The butanol and aqueous fractions were less active. Previous studies on the antimicrobial activities of plants, such as different species of Acalypha and 
Table 3. MIC of the fractions and phenolics isolated from $D$. edulis $(\mu \mathrm{g} / \mathrm{ml})$.

\begin{tabular}{lcccccc}
\hline Microorganism Gen & A & B & C & D & 1 & 2 \\
\hline E.coli NCIB 86100 & 200 & $>250$ & 200 & $>250$ & 50 & 100 \\
B. cereus NCIB 634950 & 100 & $>250$ & 250 & $>250$ & 12.5 & 50 \\
S. aureus NCIB 858850 & 100 & $>250$ & 250 & $>250$ & 12.5 & 50 \\
P. aeruginosa NCIB 95050 & 200 & $>250$ & 200 & $>250$ & 25 & 100 \\
\hline
\end{tabular}

Gen: gentamicin

different varieties of Lasianthera africana gave similar activity guided purification pattern (Adesina et al., 2000; Ajibesin and Bassey, 2011). Out of the six bulked fractions obtained from further purification of ethyl acetate fraction by column chromatography, bulked fraction $A$ gave the best activity against all the test bacteria, followed by bulked fraction $C$ (Table 2). These active bulked fractions $\mathrm{A}$ and $\mathrm{C}$ showed low minimum inhibitory concentration (MIC) values ranging from 100 to 250 $\mu \mathrm{g} / \mathrm{ml}$ (Table 3). The most active bulked fraction A yielded ethylgallate which gave the highest antibacterial activity against the test microorganisms with the lowest MIC $(12.5 \mu \mathrm{g} / \mathrm{ml})$. This activity was higher than that of Gentamicin, the standard drug. Thus, its presence accounted for the antibacterial activity of the leaves of the plant. The antimicrobial properties of ethylgallate have been established in literature (Adesina et al., 2000; Lamikanra et al., 1990; Burapadaja and Bunchoo, 1995). Bulked fraction $\mathrm{C}$ gave quercitrin which showed less antibacterial activity with the MIC value of $50 \mu \mathrm{g} / \mathrm{ml}$.

Quercitrin has been isolated from plants, such as Piliostigma thonningii (Ibewuike, 1997; Bombardelli et al., 1973), Koelreuteria paniculata (Lin et al., 2002) and Hypericum caprifoliatum (Dall et al., 2003), and its antimicrobial activity widely reported in such plants.

The antibacterial effects of $D$. edulis leaf have been determined to be mainly due to ethylgallate, while quercitrin was also isolated as antibacterial principle showing less inhibitory activity.

\section{Conclusion}

The two compounds, ethylgallate and quercitrin have been identified from the leaves of $D$. edulis, and were found to be responsible for the antibacterial effects of the plant. This validates its use in traditional medicine for treating infections.

\section{REFERENCES}

Adesina SK, Idowu O, Ogundaini AO, Oladimeji $\mathrm{H}$, Olugbade TA, Onawunmi GO, Pais M (2000). Antimicrobial constituents of the leaves of Acalypha wilkesiana and Acalypha hispida. Phytother. Res., 14: 371-374.

Ajibesin KK, Bassey ME (2011). Antimicrobial activities of the leaves of four varieties of Lasianthera africana. Inventi impact Ethnopharmacology, 1(3): 179-181.

Ajibesin KK, Ekpo BJ, Bala DN, Essien EE, Adesanya SA (2008). Ethnobotanical survey of Akwa lbom State of Nigeria. J. Ethnopharmacol., 115(3): 387-408.

Alade PI, Irobi ON (1993). Antimicrobial activities of crude leaf extracts of Acalypha wilkesiana. J. Ethnopharmacol., 39: 171-174.

Ayuk ET, Duguma B, Franzel S, Kangué J, Mollet M, Tiki-Manga T, Zekeng P (1999). Uses, management and economic potential of Dacryodes edulis (Burseraceae) in the humid lowlands of Cameroon. Econ. Bot., 53(3): 292-301.

Bilia AR, Palmae E, Marsili A, Pistelli I, Morelli I (1993). A flavonol glycoside from Agrimonia eupatoria. Phytochemistry, 32(4): 10781079.

Bombardelli E, Gabetta B, Mustich G (1973). Plants of Mozambique 1. Flavonoids of Piliostigma thonningii. Fitoterapia, 44(2): 85-87.

Bouquet A (1969). Witch doctors and traditional medicine of Congo (Brazzaville). Mem. Works and Documents of the Office of Scientific and technical Research Overseas, Paris.

Burapadaja S, Bunchoo A (1995). Antimicrobial activity of Tannins from Terminalia citrina. Planta. Med., 61: 365-366.

Burkill HM (1985). The Useful Plants of West Tropical Africa (Edition 2). Vol. 1, Families A-D. Royal Botanic Gardens, Kew.

Cos P, Vlietnick AJ, Berghe DV, Maes L (2006). Anti-infective potential of natural products: How to develop a stronger in vitro proof-ofconcept'. J. Ethnopharmacol., 106: 290-302.

Dall AR, Ferraz A, Bernardi AP, Albring D, Nor C, Sarmento L, Hass M, von Poser G, Schapoval EES (2003). Antimicrobial activity of some Hypericum species. Phytomedicine, 10(6-7): 511-516.

Duguid JP, Marmion BP, Swain RHA (1978). Mackie and McCartneys Medical Microbiology: A Guide to the Laboratory Diagnosis and Control of Infection, Vol 1: Microbial Infections, 13th edn., the English language Society and Church Livingstone, U.S.A, pp. 246- 256.

Ekong DEU, Okogun JI (1969). Terpenoids of Dacryodes edulis. Phytochemistry, 8: 669-671.

Hutchinson J, Dalziel JM (1958). Flora of West Tropical Africa. Vol. 1, part II, Crown Agents for Overseas Government, London.

Ibewuike JC (1997). Bioactivity-guided isolation of constituents of the leaves of Piliostigma Schum. Ph.D. Thesis (Pharmaceutical Chemistry), Obafemi Awolowo University, Ile-Ife, Nigeria.

Igbinosa OO, Igbinosa EO, Aiyegoro OA (2009). Antimicrobial activity and phytochemical screening of stem bark extracts from Jatropha curcas (Linn). Afr. J. Pharm. Pharmacol., 3(2): 058-062.

Igoli JO, Ogaji OG, Tor-Anyiin TA, Igoli NP (2005). Traditional medical practices among the Igede people of Nigeria. Part II. Afr. J. Trad. CAM, 2(2): 134-152.

Jirovetz L, Buchbauera G, Geissler M, Ngassoum MB, Parmentier M (2003). Comparative analysis of aroma compounds of African pears via differently coated solid-phase micro-extraction fibre (SPME) using GC-FID and GCMS. Eur. Food Res. Technol., 218(1): 40-43.

Kinkela T, Kama-Niamayoua R, Mampouya D, Silou T (2006). Variations in morphological characteristics, lipid content and chemical composition of safou (Dacryodes edulis (G. Don) H.J. Lam) according to fruit distribution, A case study. Afr. J. Biotechnol., 1233-1238.

Lamikanra A, Ogundaini AO, Ogungbamila FO (1990). Antibacterial constituents of Alchornea cordifolia leaves. Phytother. Res., 4(5): 198-200.

Lin W, Deng Z, Lei H, Fu H, Li J (2002). Polyphenolic compounds from 
the leaves of Koelreuteria paniculata Laxm., J. Asian Nat. Prod. Res., 4(4): 287-295.

Metha BK, Savita Sharma KM, Dubey A (1988). 4-ethylgallic acid from two Mimosa species. Phytochemistry, 27(9): 3004-3005.

Obame LC, Edou P, Bassole IHN, Koudou J, Agnaniet H, Eba F, Traore AS (2008). Chemical composition, antioxidant and antimicrobial properties of the essential oil of Dacryodes edulis (G. Don) H.J. Lam from Gabon. Afr. J. Microbiol. Res., 2: 148-152.
Obasi NB, Okolie NP (1993). Nutritional constituents of the seeds of the African pear Dacryodes edulis. Food Chem., 46(3): 297-299.

Onocha PA, Ekundayo O, Oyelola O, Laakso I (1999). Essential oils of Dacryodes edulis (G. Don) HJ Lam (African pear). Flavour Fragrance, 14: 135-139. 